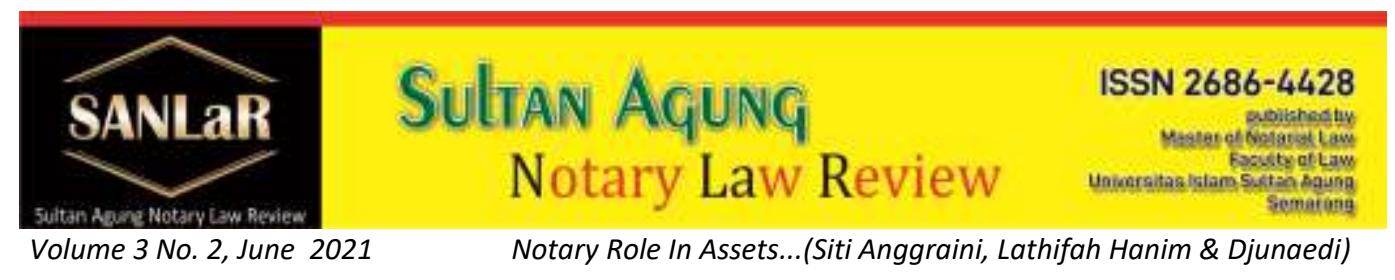

\title{
Notary Role In Assets Transfer Process From a Hospital Foundation Become a Limited Company
}

\author{
Siti Anggraini ${ }^{*}$, Lathifah Hanim ${ }^{* *}$ and Djunaedi**) \\ *) Faculty of Law, Universitas Islam Sultan Agung (UNISSULA) Semarang, E-mail: \\ sitianggraini727@gmail.com \\ ${ }^{* *}$ Faculty of Law, Universitas Islam Sultan Agung (UNISSULA) Semarang, E-mail: \\ lathifah@unissula.ac.id \\ ${ }^{* * *)}$ Faculty of Law, Universitas Islam Sultan Agung (UNISSULA) Semarang, E-mail: \\ djunaedi@unissula.ac.id
}

\begin{abstract}
The establishment of foundations in Indonesia prior to the foundation law was only based on customary law/jurisprudence in practice that developed in the community. The establishment of the foundation itself sometimes deviates from its original purpose, namely as a non-profit copper company with social, religious, and humanitarian purposes, but in the future it is not uncommon for the founders and coaches of a foundation to want to make a profit/profit from their business. The author deliberately takes a case study of a hospital foundation that changes a legal entity and its assets into a PT, namely the author wishes to be able to find out the extent of the role and responsibilities of a notary, and what about this matter when viewed from the point of view of the foundation's laws and regulations. - law PT, whether it is an unlawful act or not. The author in carrying out this case study research, uses a normative juridical method, namely by examining theories and concepts, as well as legal principles and legislation related to research. The results of the study can be concluded by the author that changing a legal entity from a foundation to a PT, is a violation of the law, because it is contrary to the laws and regulations of the foundation and the laws and regulations of $P T$.
\end{abstract}

Keywords: Asset Transfer; Foundation; Hospital; Limited Company.

\section{Introduction}

The 1945 Constitution of the Republic of Indonesia is based on law (Rechststaat), not based on mere power (Machstaat). This means that the Republic of Indonesia is a democratic legal state based on Pancasila and the 1945 Constitution of the Republic of Indonesia, upholds human rights, and 
ensures that all citizens have the same position in law and government and are obliged to uphold the law and government with no exception. ${ }^{1}$

Realizing whether or not all members of society are at the same level, especially in terms of economic capacity, humans as homo hominisocious are moved to help each other. Moreover, for the Indonesian people, the nature of mutual cooperation is ingrained, so that individuals who feel quite established will help others who are less fortunate in terms of the economy. The high level of generosity of our society is confirmed to give charity and care for the suffering of others, the work of individuals who move independently will in turn bring them together with other individuals who have the same views and goals. Groups of individuals who have the same vision and views often become so strong that at a later stage they agree to unite to form a forum that organizes their activities so that there is a transition from traditional social philanthropy to a more recent, organized and coordinated form, which is more general in nature institutions compared to individuals and aims to optimize all available resources. This institution is expected to be independent, also has its own identity that is different from the extension of the founders. In the legal system in Indonesia, these non-profit institutions are known as foundations, where a foundation has goals in the social, religious, and humanitarian fields.

The tendency of the community to choose the form of a foundation is partly because the establishment process is simple. Foundations as legal entities (rechtsperson) have been recognized and enforced as legal entities for a long time in Indonesian society, even long before Indonesia's independence. ${ }^{2}$ However, the status of the foundation as a legal entity was considered weak, because at that time the foundation's rules only came from the customs in society. The legal status of the foundation is only based on the wishes of the founders or the agreement of the founders for social purposes. But in practice, the foundation's business activities are equated with Firms, CVs, and PT. Even though the foundation carries out business activities, judging from its position, the foundation is not a company because in the company its activities carry out a business with the aim of making profit. ${ }^{3}$ Meanwhile, a foundation as a legal entity has its own assets that are separate from the assets of its management, and has a social purpose and function. In establishing a foundation, a notarial deed is required which must be made by an authorized official, namely a notary, the notarial deed is needed by the parties not only as a condition for the establishment of a foundation legal

\footnotetext{
${ }^{1}$ Evi Hartanti, 2005, Tindak Pidana Korupsi, Sinar Grafika, Jakarta.

2 Hayati Soeradjo, 1981, Status hukum yayasan dalam kaitanya dengan penataan badan-badan usaha di Indoneisa, Jakarta, p. 7

${ }^{3}$ Chatamarassjid, 2002, Badan hukum yayasan, Citra Aditya Bakti, Bandung, p. 3
} 
entity but also as evidence for him regarding existing and/or civil legal relations. happened between them and there was even an agreement between the parties, in which the agreement itself has been regulated in civil law, that the State of Indonesia still uses Burgerlijk Wetboek or the Dutch Civil Code. $^{4}$

In article 1320 of the Civil Code, the conditions for a valid agreement are:

a. Agree with those who bind themselves.

b. The ability to make an agreement.

c. A certain thing.

d. A lawful reason. ${ }^{5}$

Thus, if the conditions mentioned above are fulfilled, the agreement is binding and applies as law for those who make it.

In its development, the agreement which was originally made orally is then made in writing, this arises because it is felt important by all parties who entered into the agreement and can be used as evidence that an agreement has been entered into by the parties and becomes evidence if there is a dispute over this matter. agreed upon by the parties who made it.

The Civil Procedure Code recognizes 5 (five) types of valid evidence, which are regulated in article 164 of the Herziere Inlandsch Reglement (HIR), namely:
a. Letter
b. Witness
c. conjecture
d. Confession
e. Oath

By mentioning in the HIR that letters can be used as evidence means that it can be concluded that the deed of agreement made by a notary at the request of the

\footnotetext{
${ }^{4}$ Subekti, 1984, Aneka Perjanjian, Bandung, p. 3

${ }^{5}$ Subekti dan Tjitrosudibio, 1995, Kitab Undang-undang Hukum Perdata, Pradnya Paramita, Jakarta, p. 339
} 
parties, can automatically be used as evidence in court if each party has problems or disputes in the future. The deed itself according to its form can be divided into 2 (two) namely: authentic deed and private deed. ${ }^{6}$ Underhand deed can be made in such a way based on the agreement of the parties and the date can be made at any time, while authentic deed must be made by the authorized official, namely a notary. A deed can have a formal function (formality causa), which means that to complete or perfect a legal act, a deed must be made. Here the deed is a formal requirement for the existence of a legal act. Besides its formal function, the deed has a function as evidence (probationis causa). The deed was made from the beginning intentionally for proof/as evidence in the future in the event of a dispute or problem between the parties. The authentic deed will clearly state the rights and obligations, guaranteeing legal certainty, for each party to the agreement. An authentic deed made by a notary, not only because it is required by legislation but because it is desired by interested parties to ensure the rights and obligations of the parties for the sake of certainty, order and legal protection for interested parties, so that the notary has an obligation to include that what is contained in the notarial deed has truly been understood and in accordance with the wishes of the parties, namely by reading it out so that it becomes clear what is contained in the contents of the notarial deed, as well as providing access to information, including the laws and regulations related to the parties involved sign the deed. Thus, the parties can freely determine whether or not to agree with the contents of the notarial deed to be signed.

Since the author in this case takes a case study of a hospital that is a foundation legal entity and then turns into a PT hospital, the definition of a hospital will be described first based on the Decree of the Minister of Health of the Republic of Indonesia Number 340/MENKES/PER/III/2010, namely service institutions health services that provide complete individual health services that provide inpatient, outpatient and emergency services. Meanwhile, the definition of the foundation itself according to article 1 number (1) of Act No. 28 of 2004 concerning amendments to Act No. 16 of 2001 concerning foundations, that a foundation is a legal entity consisting of assets that are separated and intended to achieve certain goals in the social, religious fields and humanity. ${ }^{7}$ So in this case there is a relationship between a Notary as a public official who has the authority to make an authentic deed, with the making of a deed related to the making of a deed of establishment, a deed of amendment to the articles of association and the deed of dissolution of the foundation, and also a notary is a professional official who is considered to understand the all the rules regarding the laws and regulations or other regulations concerning/in connection with the deed he made. However, in reality the notarial deed is not based on the applicable legal provisions, as long as

\footnotetext{
${ }^{6}$ Niniek Suparni, 1991, Kitab Undang-undang Hukum Perdata, Rineka Cipta, Jakarta p. 465 ${ }^{7} \mathrm{http}$ : //general-understanding. Blogspot.com/understanding of roles in general, accessed on November 18, 2020, at 20.35 WIB
} 
the notarial deed for the establishment of the Selaguri Hospital Foundation, there is no problem with the notary deed, and everything is in accordance with the foundation's statutory regulations but starting at the stage of disbanding the foundation where the dissolution of the foundation was indeed desired by the founding parties of the foundation, here there is confusion that the dissolution of the foundation is not based on Act No. 28 of 2004 concerning Foundations again, which if the foundation is dissolved, all its assets must be handed over to other foundations that have similar activities, it is not allowed that assets from the disbanded foundation are then divided up distribute it to the founders as personal assets, moreover the assets from the division of the dissolution of the foundation are used as capital/shares in the creation of PT. Selaguri Citratama Medika, this clearly violates the rules, both in terms of the foundation law and the PT law itself.

\section{Research Methods}

\section{a. Approach Method}

Based on the background and formulation of the problem that has been described, this research uses a normative juridical method, namely a research approach that is carried out by examining theories, concepts and principles of law and legislation relating to roles and responsibilities the notary's responsibility in changing the assets of the hospital foundation which turned into a limited liability company (PT).

\section{b. Research Specifications}

Based on the background and problem formulation that have been described, this research is a normative research or commonly referred to as doctrinal legal research, namely research conducted by examining library materials related to the case studies in this study.

\section{c. Data Retrieval Method}

In this case study, researchers used several data sources, namely:

\section{1) Primary data}

Obtained from sources or informants. To get a complete description of the object under study, the researcher used a data collection tool by conducting interviews with informants/informants based on a list of questions that had been prepared beforehand.

2) Secondary Data 
Secondary data as supporting or complementary data, obtained from the literature and various literatures or references to a number of books that are relevant to the problems that have been formulated and consist of:

a) Primary Legal Materials.

In this study, the primary legal materials consist of the basic principles in Indonesian law, namely:

- Act No. 2 of 2014 concerning the Position of Notary

- Act No. 28 of 2004 concerning amendments to Act No. 16 of 2001 concerning Foundations.

- Act No. 40 of 2007 concerning Limited Liability Companies (PT).

- Government Regulation (PP) Number 63 of 2008 concerning the Implementation of the Law on Foundations.

- Government Regulation (PP) Number 2 of 2013 concerning amendments to Government Regulation (PP) Number 63 of 2008 concerning the implementation of the Law on Foundations.

b) Secondary Legal Material

Secondary Legal Materials are legal materials that provide explanations for primary legal materials and are obtained indirectly from the source, in other words collected by other parties, in the form of legal journals, official documents, research in the form of reports, and legal books.

c) Tertiary Legal Materials.

Tertiary Legal Materials, namely materials that provide instructions or explanations for primary and secondary legal materials, such as legal dictionaries, indexes of legal magazines, legal research journals, and materials outside the field of law, such as magazines, newspapers, and search results materials sourced from the internet related to the problem under study.

\section{d. Method of collecting data}

The technique of collecting legal material that supports and relates to the presentation of this legal journal writing is the normative juridical approach, which is an approach that is based on the main legal material by examining 
theories, concepts, legal principles and laws and regulations. related to this research, as well as interviews with Dr. Mulyoto, SH, M.Kn, as a lecturer in the course on Foundation Legal Entities at the Faculty of Law, Masters of Notary Department, Sultan Agung Islamic University, Semarang, and also Mr. Affandi, $\mathrm{SH}, \mathrm{M} . \mathrm{Kn}$ as a notary in the city of Kudus, both as resource persons in this case study.

\section{e. Data analysis method}

The technique of analyzing legal materials in this study uses qualitative analysis, meaning that it describes the data obtained and then processed in detail into the form of (descriptive) sentences. Based on the results of the analysis, conclusions are drawn deductively, namely a way of thinking based on general facts and then drawing a specific conclusion.

\section{Results and Discussion}

3.1. Roles and Responsibilities of Notaries in the Process of Transferring Legal Entities and Assets of Selaguri Hospital Foundation to become PT. Selaguri Citratama Medika

Based on the results of research conducted by the author through interviews with informants who know about the case in this study, namely Dr. Mulyoto, $\mathrm{SH}$, M.Kn, that he explained that Selaguri Hospital was established in June 1983, which is located on Jalan Ahmad Yani number 26, Padang. This hospital started as a simple polyclinic which was founded by a doctor named dr. HM Zein Zainuddin, Sp. ENT. The ENT clinic used to be called "Ahmad Yani Foundation", then in April 1986 the founder and also the doctor who practiced there changed it from a clinic to a hospital then the name of the clinic was also changed to "Selaguri Hospital Foundation". In the course of the hospital progressed quite rapidly and significantly.

Based on the information that the author got from interviews with interviewees as informants in this study, that regarding the history of the early establishment of the Selaguri foundation, which was previously named the Ahmad Yani foundation, was established in a remote area, and just stood there was no basic administrative official establishment in accordance with the founding regulations. He also said that the establishment of the foundation at that time had no provisions regarding the selection of the type of business entity that was specifically intended to establish a clinic or a hospital. At that time the government still did not care about business entities that had sprung up in Indonesia, which resulted in the founders of the Selaguri foundation acting aloneand on his own initiative he also established a clinic with the legal entity of a foundation. The selection of the legal entity of the foundation according to the 
founder was carried out only based on the existing and developing habits in society at that time, and for other reasons, namely the ease of establishing a foundation and tax relief provided by the government to all foundations in Indonesia. The Indonesian government at that time was led by President Suharto, who supported the proliferation of foundations in Indonesia. After nineteen years, the Selaguri hospital foundation was established and operated based on the existing habits of the community in dealing with the problems faced by the government, both to the Selaguri foundation in particular and to foundations throughout Indonesia in general. After a long time the community has carried out foundation activities for social purposes and the government itself has never carried out any supervision or action, so that the founders of the foundation felt they had never made a mistake, and it turned out that in the field there were many cases that there had been deviations from purely social goals foundations, then in 2002 the government issued a law that regulates the operation of foundations, namely Act No. 16 of 2001 and its amendment to Act No. 28 of 2004 concerning Foundations. Responding to the birth of these laws and regulations, on the one hand there is legal certainty governing the existence of foundations in Indonesia, but on the other hand the founders of the foundation who had established and operated the foundation using the founder's personal wealth without any donations from any party, were worried about the continuation of the hospital he had founded. Based on this, after the enactment of the foundation law, the founder feels that there must be a followup as soon as possible to take concrete action against the emergence of new government regulations regarding foundations, so as not to threaten the continuation of the operating activities of the Selaguri hospital. Selaguri Hospital agreed to dissolve the Selaguri hospital foundation for several basic reasons, namely:

a. Adjustment to the provisions of Articles 3 and 5 of Act No. 16 of 2001 concerning Foundations which prohibits the distribution of profits to the organs of foundations. Regarding this rule, it is considered quite contradictory to the wishes of the founders, because the benefits obtained from all health service activities to the community at Selaguri Hospital are needed to finance all operational costs and salaries of hospital employees. The dissolution of the foundation was disbanded because it was deemed inappropriate that a foundation should function socially with a profit-seeking orientation, and also to avoid being subject to criminal threats that it had violated the rules stipulated by the foundation law.

b. In order to obtain legal certainty regarding the continuation of the Selaguri hospital foundation, that in its establishment, the foundation used was only on the basis of custom, doctrine and jurisprudence. 
c. The dissolution of this foundation is feared to have an impact on the wealth of the foundation if the founder dies later, that it is based on the laws and regulations regarding the foundation if the foundation is dissolved then all the assets of the foundation will be transferred to a foundation of similar nature and activities, and if there is no similar foundation then the transfer of all assets of the foundation will be given to the state/government, regulations regarding this are very worrying for the founder of the foundation, because the Selaguri hospital foundation he founded without any help from the government or any donors. For this reason, the founder also hopes that one day one of his descendants can continue the implementation of Selaguri hospital activities, because one of his children/founder of Selaguri hospital who also works as a doctor. From the very beginning, the hospital was founded with the intention that apart from accommodating people who need health services, they also wished to seek profit from their activities, as stated in Article 3 paragraph (2) of Act No. 28 of 2004 concerning Foundations states that "Foundations may not share the results of business activities. and/or participate in a business entity, the provisions in that paragraph are in accordance with the aims and objectives of the foundation which are social, religious, and humanitarian in nature, so that a person who becomes the supervisor, administrator, supervisor of the foundation must work voluntarily without receiving a salary/wages, or fixed honors. And also in article 5 paragraph (1) of Act No. 28 of 2004 concerning Foundations, it is stated that "The assets of the foundation are in the form of money, goods. ${ }^{8}$

The transfer of legal entities and assets of Selaguri Hospital from a foundation to a PT does not escape the role of a notary, where the position of a notary is essentially a public official (privatenotary) assigned to serve the needs of the community for authentic evidence that provides civil law certainty, so as long as authentic evidence is still needed by the state legal system, the position of a notary will still need its existence in the community.

Deed has a formal function (causa formality), which means that to complete or perfect a legal act, a deed must be made, while the notary himself has the position as a public official authorized to make authentic deeds and other authorities regulated in Act No. 30 of 2004 concerning the Position of a Notary, means that it can be concluded that a notary as a public official has the authority to make an authentic deed regarding all acts, agreements, and provisions required by legislation and/or desired by the interested parties to be stated in an authentic deed, guarantee the certainty of the date of making the deed, keep the

${ }^{8}$ Act No. 28 of 2004 concerning Foundations 
deed, provide grosse, copies and quotations of the deed, all of this as long as the making of the deeds is not assigned or excluded to other officials or other people stipulated by law. Meanwhile, based on the laws and regulations concerning foundations and the Company Law, it has stipulated that the establishment of legal entities, both foundations and limited liability companies, must use a deed made by a notary/based on an authentic deed.

Responding to the description of the case that the author studied, then the author conducted an interview with Mr. Mulyoto as the party who provided information from the case study that the author was researching, he said that since the founder of the hospital wanted to change the legal entity and assets of the Selaguri hospital foundation into PT, the founder come to the notary Mr. Hendri Final to ask for advice and suggestions as well as what steps must be taken to achieve this the intention and desire of the founder to change the legal entity of Selaguri Hospital. The founders of the hospital are only ordinary people who do not understand all the laws and regulations governing the establishment and changes related to legal entities in Indonesia, therefore the founders just follow the input and advice of a notary who is considered a professional official who understands the regulations better law, especially with regard to business legal entities. From here, the founder began to implement and follow up on whatever was suggested by the notary Mr. Hendri Final, where the notary gave a suggestion that the founder of Selaguri Hospital make an application for the transfer of a business license to the Minister of Health, the permission requested was in the form of a hospital operational transfer permit from a foundation to PT, by giving reasons that the founders no longer have the ability to take care of the foundation again. The Ministry of Health also issued a permit for the operational shift, then after that the hospital foundation was dissolved. With the dissolution of the hospital foundation, the notary also provides suggestions that all assets of the foundation be calculated both liabilities and assets, by requesting assistance from a public accountant, after calculating the assets then the distribution of these assets by the hospital founder plans to include all the assets divided by the foundation. Selaguri Hospital which was dissolved earlier as a share in the establishment of a new limited liability company (PT), as well as all the deed of transfer made in the form of a notarial deed by Mr. Hendri Final as a notary. Since the founder of the Selaguri hospital foundation felt that all the time the hospital's establishment had come from personal wealth without any help or donations from any party, so after the hospital foundation was dissolved there was no news at all in the local daily newspaper, because according to him there was no need for notification the dissolution of the hospital foundation to the public. In this case, the notary has an important role to make the notarial deed from the stage of establishing the Selaguri hospital foundation, as well as all changes to its articles of association, until the dissolution of the foundation to the change of the legal entity and all assets of the Selaguri hospital into a 
hospital limited liability company which then uses the name of the hospital with PT. Selaguri Citratama Medika.

\subsection{Changes in Legal Entities and Assets of Hospital Foundations to Limited Liability Companies (PT) in terms of Act No. 28 of 2004 concerning Foundations and Act No. 40 of 2007 concerning Limited Liability Companies (PT)}

a. From the point of view of Act No. 28 of 2004 concerning Foundations

The hospital foundation which was originally a legal entity and after a long period of existence as a foundation was later changed to a PT, namely the change was carried out by first dissolving the foundation, then the assets of the foundation were transferred to the capital of the newly established PT. The composition of the PT organ was carried out by reappointing several people who used to be members of the organs of the foundation and later became the founders of the established PT.

In this case the question is: is the legal act of changing the legal entity of the foundation that operates the hospital to be changed to the legal entity of the PT that operates the hospital, by dissolving the foundation first, can it be justified according to the foundation law and the PT law?

There are several people who set up foundations, with social purposes and activities in the form of hospitals (the social goals are stated in the foundation deed). The founders of the foundation organs initially did not understand that: the assets of the foundation, whether in the form of money, goods or other assets obtained by the foundation, based on the foundation law, are prohibited from being transferred or distributed directly or indirectly to supervisors, administrators, supervisors, employees, or other parties who have an interest in the foundation (Article 5 of Act No. 16 of 2001 concerning Foundations).

In fact, every organ of the foundation that violates the provisions as referred to in Article 5 shall be punished with imprisonment for a maximum of 5 (five) years. In addition to imprisonment, members of the foundation organs are also subject to additional penalties in the form of an obligation to return money, goods or assets of the foundation that are transferred or distributed (article 70 paragraphs (1) and (2), Act No. 16 of 2001 concerning foundations).

The provisions as regulated in Article 5 of Act No. 16 of 2001 concerning Foundations, were later amended in Article 5 of Act No. 28 of 2004 concerning Amendments to Act No. 16 of 2001 concerning the foundation which reads:

1) The assets of the foundation, whether in the form of money, goods or other assets obtained by the foundation based on this law, are prohibited 
from being transferred or distributed directly or indirectly, either in the form of salaries, wages, or honorariums, or in other forms that can be valued in money to the builder administrators and supervisors.

2) Exceptions to the provisions as referred to in paragraph (1), it can be determined in the articles of association of the foundation that the management receives a salary, wages, honorarium, in the event that the management of the foundation:

a) Not the founder of the foundation and not affiliated with the founder, supervisor and supervisor

b) Carry out direct and full management of the foundation.

3) The determination of the salary, wages and honorarium as referred to in paragraph (2) shall be determined by the supervisor in accordance with the ability of the foundation's assets.

While the criminal threat as regulated in Article 70 of Act No. 16 of 2001 concerning Foundations may not be changed, although later in Article 5 paragraph (2) of Act No. 28 of 2004, it is possible for management to receive salaries, wages, or honorariums, if the management was not founder of the foundation and not affiliated with the founder of the foundation, and carry out the management of the foundation directly and fully.

The founders of the foundation who at the time of establishing the foundation whose purpose and business activity was to establish and operate a hospital had set aside a lot of wealth in the form of plots of land and a sum of money, and then after the hospital developed and even its assets increased as a result of people who use the hospital's services in the sense that there are really a lot of patients, then they realize that according to the foundation law, the trustees, administrators, and supervisors of the foundation are not allowed/forbidden to accept any wealth acquired by the foundation. The prohibition by the Foundation Law is a natural thing because foundations are social bodies that have noble aims and objectives, namely: social, religious, and humanitarian so that foundations are non-profit legal entities.

The process of the hospital foundation becoming a hospital PT that has been carried out/occurs, is with the following stages:

a) First, dissolve the foundation and calculate all existing assets.

b) The existing assets of the foundation are then transferred to the capital of the PT to be established. 
c) Arrangement of organs, namely reappointing several people who used to be members of the organs of the foundation and then become the holders/shareholders of the PT to be established.

d) Each of the prospective founders of a PT which in fact was originally a member of the organ of the foundation gets/receives a certain amount of money/remaining from the liquidation of the foundation.

e) The amount of money received by each of the prospective founders of the PT is the amount of money which is then placed, taken part and deposited into the company's treasury.

An incident which is a series of legal actions, and those legal actions have been through or have been handled by competent officials, it turns out that such a thing turns out to be a series of legal actions that clearly violate the laws and regulations applicable.

An incident in the form of a legal action/action changing the legal entity of a foundation that originally operated a hospital, then changed it to a PT that both operates a hospital, to find out what the series of steps are, the legal actions violate the Foundation Law and/or the Company Law it is necessary to examine how the articles in the Foundation Law and the Company Law sound in relation to these legal acts.

3.3. The foundation law (Act No. 16 of 2011 Jo. Act No. 28 of 2004) and the Company Law (Act No. 40 of 2007) have prohibited

a. Foundation Law (regarding foundation assets):

1) Article 3 of the Foundation Law

- Paragraph (1) foundations can carry out business activities to support the achievement of its goals and objectives by establishing a business entity and/or participating in a business entity.

- Paragraph (2) foundations may not distribute the results of business activities to the Trustees, Management and Supervisors.

2) Article 5 in conjunction with Article 70 of the Foundation Law.

Article 5 of the Foundation Law states that: "Wealth in the form of money, goods, or other assets obtained by a foundation is prohibited from being transferred or distributed directly or indirectly in the form of salaries, wages, or 
honorariums or other forms that can be valued in money to the Trustees, Managers and Supervisors.

In case, the remaining wealth resulting from the liquidation of the disbanded/disbanded foundation was actually distributed to the prospective founders of the PT, which incidentally they were originally members of the foundation's organs (Guidance, Management/Supervisor of the foundation) so that it was an act (distributing the remaining wealth resulting from the liquidation of the foundation) is an act that violates the provisions of Article 5 of the Foundation Law. According to Article 70 of the Foundation Law, it is threatened with imprisonment for a maximum of 5 years and is subject to additional punishment in the form of an obligation to return money, goods or assets of the foundation that are transferred or distributed.

3) Article 68 of the Foundation Law (regarding the remaining assets resulting from the liquidation of the foundation)

- The remaining assets resulting from the liquidation are handed over to other foundations that have similar activities with the disbanded foundation.

- The remaining assets resulting from the liquidation as referred to in paragraph (1) may be transferred to another legal entity that has similarities with the disbanded foundation, if this is regulated in the law concerning the legal entity.

- In the event that the remaining assets resulting from the liquidation are not handed over to other foundations or other legal entities as referred to in paragraphs (1) and (2), such assets are handed over to the state and their use is carried out in accordance with the activities of the disbanded foundation.

Article 68 paragraph (2) states that the remaining assets resulting from the liquidation of the foundation can be transferred to another legal entity, which has the same activities as the disbanded foundation, if this is regulated in the law concerning the legal entity.

From the sound of article 68 paragraph (2) there are 3 (three) things that must be considered, but ignored or ignored by all parties related to the concrete case, namely:

1) The first phrase of article 68 paragraph (2) of Act No. 28 of 2004 is "submitted to another legal entity", so that the legal entity to which the 
remaining assets from the liquidation of the foundation will be transferred, the legal entity in this case a limited liability company, must have exist prior to receiving delivery of the remaining assets resulting from the liquidation of the foundation.

It is different with the stages of events that have occurred in the concrete case, namely the remaining assets from the liquidation are limited to being handed over to the prospective founders of the PT, so that the PT that will be entrusted does not yet exist, moreover, it is clearly not yet a legal entity.

The legal entity PT that will be entrusted with the remaining assets from the liquidation of the assets will only be established, even to establish PT the new founders are limited to relying on the surrender of assets/remaining liquidation proceeds of the foundation, to take shares of the authorized capital which is determined to be placed and paid in the company's cash which is only to be established.

So that what is meant by being handed over to another legal entity is that the legal entity already exists, in the sense that the establishment of the PT has received approval from the Ministry of Law and Human Rights of the Republic of Indonesia (again, it is not a PT which is only limited to being established by former people who used to be members of the organs of the foundation ).

2) The second phrase of article 68 paragraph (2) of Act No. 28 of 2004: "which has the same activities as the disbanded foundation".

From the sound of the phrase, it means that the legal entity Limited Liability Company (PT) entrusted with the remaining assets from the liquidation of its activities must be exactly the same as the dissolved foundation.

The activities of a foundation are the elaboration of the aims and objectives of the foundation. Whereas the purpose and objective of the foundation is noble, in case is the social field of organizing a non-profit hospital.

Although the activities of a PT are both hospitals, it is actually different from a hospital run by a foundation legal entity. Hospitals run by foundation legal entities have a noble purpose, so the emphasis is more on helping others or people who are sick and not prioritizing so that the hospital gets the maximum benefit. The sick person is a legal entity of PT, so the priority is to get the maximum profit (profit).

The question is, can it still be said that the activities of the PT are the same as those of the disbanded foundation? In the author's opinion, they are not the same or different or at least not completely the same. 
3) The third or last phrase of article 68 paragraph (2) of Act No. 28 of 2004 "if it is regulated in the law regarding the legal entity".

From this farsa, it requires that the provisions for receiving the remaining assets from the liquidation of the foundation must have been regulated in the law that will receive it (in case the receiving legal entity is PT).

b. The Limited Liability Company Law (UUPT) regarding the increase in the wealth of PT.

In UUPT No. 40 of 2007 concerning Limited Liability Companies, does not regulate the increase in the wealth of PT.

What is regulated in Article 37 to Article 43 of the Company Law is limited to the protection of the company's capital and assets. Article 37 to article 40 only regulates the repurchase of shares that have been issued by the company, and articles 40 to article 43 only regulates the addition of capital and is carried out based on the approval of the General Meeting of Shareholders (GMS).

In fact, starting from Article 1 to Article 161 (the last article in the Company Law) there is nothing stipulating whether it is permissible to increase the company's wealth from the transfer of the remaining assets resulting from the liquidation of the disbanded foundation. In case it is intended that when the remaining assets are handed over from the liquidation of the disbanded foundation, the PT (company) does not yet exist (it is about to be established).

That the parties related to the legal action/deed of changing or transferring, which was originally a hospital foundation into a Hospital Limited Liability Company (PT) are:

1) The people who originally founded the foundation, later became the founders of PT.

2) The notary who makes the deeds of dissolution of the foundation, the liquidator's report on the dissolution of the foundation, the dissolution of the liquidator before the end of the legal entity status of the foundation, the establishment of a PT Hospital.

3) Land Deed Making Official (PPAT) who makes a grant deed or sale and purchase of foundation assets in the form of a certain plot of land along with the hospital building located on it.

4) Officer/officer of the registration of the transfer of land rights. 
5) Corrector at the Director General of AHU, Ministry of Law and Human Rights (HAM) of the Republic of Indonesia.

The question is whether the parties concerned as mentioned above really understand that:

1) All steps/actions/legal actions of members of the organs of the foundation should only be limited to achieving the aims and objectives of the foundation.

2) After the foundation has received a letter of approval from the Ministry of Law and Human Rights of the Republic of Indonesia or after becoming a legal entity, all and all assets of the foundation are the property of the foundation itself, even the property of the community.

3) Foundations are not allowed to share the results of their business activities with the trustees, administrators and supervisors of the foundation.

4) The assets of the foundation, whether in the form of money, goods, or other assets obtained by the foundation, are prohibited from being transferred or distributed directly or indirectly in the form of salaries, wages, or honorariums or other forms that can be valued in money to supervisors, administrators, and supervisors.

5) The remaining assets resulting from the liquidation of the disbanded foundation can only be used to justify their use in accordance with the activities of the disbanded foundation.

6) The remaining assets resulting from the liquidation of the disbanded foundation can only be justified to the extent of being handed over to another foundation which has the same activities as the disbanded foundation.

7) Hospitals operated by foundation legal entities which are themselves non-profit and hospitals operated by PT which automatically become profit, can be said to be legal entities that do not have the same activities or at least are not exactly the same.

8) Another legal entity entrusted with the remaining assets from the liquidation of the foundation, (in case of a PT), then the said PT must already exist in the sense that it has received a Decree (SK) endorsement from the Minister, not limited to the new PT to be established. 
9) Other legal entities that have similar activities, the law of the other legal entities must stipulate that the remaining assets resulting from the liquidation of the disbanded foundation are allowed to be handed over to the legal entity.

10) In Act No. 40 of 2007 concerning PT, it turns out that there is no article that allows/justifies the transfer of the remaining assets from the liquidation of the disbanded foundation to PT.

- Can a foundation legal entity be justified (according to the law/Foundation Law) to donate its assets in the form of a certain plot of land along with the hospital building located on it to a PT or to another legal entity/any party/any party?

- Can a foundation legal entity be justified according to law (the Foundation Law) to sell its assets in the form of a certain plot of land along with the hospital building that is above it, and the money from the sale of these assets is not used for the development or achievement of the foundation's goals and objectives?

\section{Closing}

Based on the fact that it turns out that the change from the legal entity of the foundation that runs the hospital to the hospital PT has actually been implemented, so from the many questions as mentioned above, it can be assumed that it is even certain that the answer is that the parties do not understand all the rules/ regulations relating to the transfer of assets from a legal entity foundation to PT Selaguri Hospital.

\section{References}

Books:

[1] Evi Hartanti, 2005, Tindak Pidana Korupsi, Sinar Grafika, Jakarta

[2] Chatamarassjid, 2000, Tujuan sosial yayasan dan kegiatan usaha bertujuan laba, Bandung, Citra Adtya Bhakti

[3] Hayati Soeradjo, 1981, Status Hukum Yayasan dalam kaitanya dengan penataan badan-badan usaha di Indonesia, Jakarta

[4] Subekti, 1984, Aneka Perjanjian, Alumni, Bandung

[5] Subekti dan R. Tjitrosudibio, 1995, Kitab Undang-Undang Hukum Perdata, Pradnya Paramita, Jakarta 
[6] Ninik Suparni, 1991, Kitab Undang-undang Hukum Perdata, Rineka cipta, Jakarta

Regulations:

[1] Constitution 1945

[2] Code of Civil law

[3] Act No. 2 of 2014 concerning Notary Position

[4] Act No. 28 of 2004 Amendments to Act No. 16 of 2001 concerning 2001 Foundation

[5] Act No. 40 of 2007 Limited company.

[6] Act No. 44 of 2009 concerning Hospitals

Internet:

http://umum-pengertian-blogspot.com/2016/06/pengertian-role-generally accessed on November 18, 2020 